DOI https://doi.org/10.36059/978-966-397-104-9/29-51

\title{
INFORMATION TECHNOLOGIES IN ECONOMY
}

\section{Medvediev M. H.}

\section{INTRODUCTION}

Information technology in the economy is a virtual economy tool. The virtual economy is an environment, a special economic space in which the e-business is implemented, that is, an economy based on the use of interactive capabilities. This space is characterized by specific features that distinguish the virtual economy from the ordinary, non-virtual, offline economy. The virtual economy is often referred to as a new economy to emphasize its distinction from the old, traditional economy.

Let's consider the details of the new economy. The basis of economic activity is business. In the virtual economy, there is the concept of e-business.

An e-business is a revenue-generating company based on digital technology and the benefits that it provides. Areas of application of e-business: e-commerce; mobile trade; financial transactions; purchase and sale of an information product; buying and selling through vending machines; banking operations; buying and selling through a virtual store; household services market; insurance operations; stock market transactions; operations with foreign currency.

The concept of "e-business" includes many different information technology concepts: technology e-commerce; technology of electronic auctions; electronic banks; IP telephony; Internet telephony; electronic pointers technology; electronic research and development; electronic franchising; Email; e-marketing; electronic resource management (ORM); electronic supply management; electronic brokerage services; information technologies of acquaintances.

Let's consider more these concepts. E-Commerce Technologies. E-commerce (e-commerce) is one way of doing business with e-commerce. Considering the problems of e-commerce, one should pay attention to the double interpretation of the term. Sometimes, speaking of e-commerce, it refers solely to the commercial activities of Internet Service Providers (ISP), but much more often, e-commerce has a wider interpretation and is 
seen as a set of all possible ways to use the Web for commercial purposes. Internet Service Provider is a commercial firm that provides access to the Internet by supporting it for a fee and carries out some related services on demand of customers. The term "e-commerce" combines many different technologies: EDI (Electronic Data Interchange Protocol); Email; Internet; Intranet (information exchange within the company); Extranet (sharing information with the outside world) ${ }^{1}$.

The most advanced information technology on which electronic commerce can be based is Electronic Data Interchange (EDI), which is a method for encoding and processing sequential transactions in on-line mode. Technologies of electronic auctions. Electronic auctions are part of a new type of markets - electronic trading markets (ETM) whose purpose is to build buyers and sellers. The main means for the implementation of electronic auctions - the Internet ${ }^{2}$.

At electronic auctions the price is not fixed. Online revenue sources, that is, electronic auctions - transaction fees and advertising. This is a very promising field of e-commerce. Many companies use electronic auctions as a marketing assessment tool that allows you to determine the primary demand and market price of a relatively new product. On the Internet auctions can be exhibited any goods that are most suitable for auction trade: computers and accessories, as well as new high-tech products for the market; reduced prices of goods; non-market goods; recent sales leaders; collectible goods.

Online auctions are categorized based on their division in the direction of growth or decline.

Bet may increase from the minimum to the maximum or, conversely, decrease from the first maximum to a certain winning minimum determined by the method.

In connection with the promise of auctioning on the Internet is now particularly popular among the various auction theories, which are becoming one of the most fashionable sections of economics.

Electronic banks. Electronic banking is carried out in two forms: services provided by electronic banks, and services provided by traditional banks, but online.

\footnotetext{
${ }^{1}$ Игер Б. Работа в Internet. Под ред. А. Тихонова; Пер. с англ. - Москва: БИНОМ, 1996. 313 с.

2 Крол Эд. Все об Internet: Руководство и каталог. Пер. с англ. С.М. Тимачева. Киев: BNV, 1995. $591 \mathrm{c.}$
} 
The basis of the emergence and development of Internet banking (Internet-banking) are the types of remote banking, the existence of banking, used at the earliest stages:

- banking - access to a bank account using a personal computer, which is carried out by means of direct dial-up connection to the banking network;

- telephone banking - account servicing by phone;

- video banking - the system of interactive communication of the client with the bank staff.

Internet banking can be defined as management of bank accounts via the Internet.

Online banks have a great future. These forecasts are due to the number of advantages that electronic banks provide to their customers. Smart Cards create the following conveniences for customers who previously seemed unattainable: round-the-clock mode of operation, uninterrupted service availability.

Internet banking involves customer service through the Internet by providing them with a wide range of services:

- open deposits;

- purchase and sale of currency and securities;

- translation;

- receiving an account statement and much more.

Customers can check the status of their accounts without leaving the office or home from any geographical point of the world and at any time of the day. Thus, there is a significant savings on the maintenance of private clients as a result of automation of this process, especially in the case of an integrated approach to the use of electronic capabilities:

- the formation of a home bank;

- creation of an electronic trading market (ETM);

- promotion of payment schemes for e-commerce, etc.

However, as long as the banking sector is concerned not with the transition to the online regime, but rather on the parallel use of traditional business practices and the opportunities provided by new information technologies. It should be borne in mind that besides purely commercial effect, electronic services in the banking sector affect the image of the bank. 
Internet banking gives customers the opportunity to get a full range of services in one system: pure banking services (access to accounts, financial transactions, etc.), insurance services, corporate finance management services, etc.

IP telephony. VoIP is the most powerful communicative information technology.

In recent years, the rapid growth of data transmission systems has led to the fact that many of the usual consumer services are now provided in a new way: e-mail has replaced traditional, electronic commerce allows you to order and pay for goods without leaving the house, etc. Today, VoIP is already beginning to compete with traditional telephony operators. One of the significant advantages of VoIP is the significantly lower cost of voice traffic compared with the cost of public telephone network services. VoIP enhances the efficiency of everyday activities of companies, introducing into the telephone all that useful, which has become familiar to users of computer networks - the ability to work with e-mail messages, obtain operational data from ERP-system production applications, as well as summaries, reports and news from the Internet / Intranet.

With the introduction of integrated voice, graphics, video and data systems, it has become possible to create fundamentally new, contemporary, user-friendly applications that convert an IP phone to a fully functional office computer. Such a phone that implements a wide range of services is a small computer with a built-in XML browser for performing various XML applications. IP telephones, in addition to supporting traditional telephone functions, provide access to the corporate directory of subscribers with search and dialing capabilities. The built-in service menu allows an IP-phone user to access textual or graphical information located on Web-servers.

Operational access to the entire volume of corporate and other data through an IP phone is usually provided through the Enterprise Information Portal (EIP). An IP phone in this case is considered as a "super-thin" client. From the user's point of view, this is a unique opportunity to gather all the information that is needed for him at the moment to perform his official duties on one screen.

IP-telephony (Internet-Phone telephony) is a technology used on the Internet to transmit speech signals. When talking, voice signals (pronounced words) will be converted into compressed data packets. These 
data packets are then sent to the other party over the Internet. When the data packets reach the destination, they are decoded in the voice signals of the original.

IP telephony is a way to organize a corporate telephone network, without investing significant funds in the creation of lines and reducing the cost of paying for telephone services.

There are two basic types of IP telephone calls: from computer to computer or from computer to phone.

IP telephony uses the dedicated digital channels as lines of telephone traffic transmission.

The Internet fundamentally changes our perceptions of both telephony and ways of communication. Although telephone networks and data networks have coexisted for decades, they have evolved independently of each other. IP telephony unites them into a single communication network, which offers a powerful and economical means of communication. Dozens of companies around the world offer commercial solutions for IP telephony. All major telecommunications companies have begun research to better understand emerging prospects. VoIP combines voice and data in one network and offers cheap long distance and international calls and a range of communications services to any user.

The general principle of IP telephony servers is as follows: on the one hand, the server is connected to telephone lines and can connect to any phone in the world. On the other hand, there is an Internet-based server that can connect with any computer in the world. The server accepts a standard telephone signal, digitizes it (if it is not digitized before), it compresses, breaks down into packets and sends them over the Internet using its Internet Protocol (TCP/IP).

For packets that come from the Web to the phone server and go to the telephone line, the operation is in reverse order. Both components of the operation (signal input to the telephone network and its exit from the telephone network) occur almost simultaneously.

Based on these basic operations, you can build many different configurations. Therefore, in the market of telephone services, a new category of operator-providers - ITSP (Internet Telephone Service Provider) - has been introduced, offering services for interacting Internet users with subscribers of telephone networks. 
Internet-telephony. Internet telephony is a special case of IP telephony. In this system, ordinary channels of the Internet are used as transmission lines. Internet telephony is partly based on the existing network of fixed telephone lines.

The concept of voice over the network using a personal computer originated at the University of Illinois (USA) in 1993. Already a year have become quite common connections over the Internet of two telephone subscribers, located in completely different places on the planet. And for only two years, until 1995, an alternative way of telephony was developed.

Technology of electronic pointers. With the help of electronic pointers, Internet customers are able to search for products and services on the Web.

Digital $R W$ and $R D W$. RW - research works is a series of research that is conducted with the aim of obtaining new knowledge, finding new ideas, principles, methods and ways of creating new or upgraded products. RDW - research and development work is a set of interconnected processes for the creation of new or modernizations of existing structures, products in accordance with the requirements of customers, the manufacture and testing of their research or master samples.

Electronic franchising - this agreement on the conditions of joint activity between the company and the dealer, according to which the dealer obtains the right to operate with the use of the trademark of the company, its know-how, marketing techniques, technologies, promotional opportunities, semi-finished products, etc., paying for this deduction of a certain Percentage of turnover or profit.

According to the New Economic Dictionary, the term "franchising" has gone from the English "franchise" - privilege. Franchising is a form of economic integration of large and small businesses, which is to give a large company (franchisor) the right to act under its trademark of a small company that is an independent legal entity. At the same time, the franchisor can give a loan, be a surety when receiving a loan. Franchising is widely used in trade, hotel business and consumer services.

Franchising can be divided into three parts:

- franchising as a form of replication of business technology (a striking example - the McDonald's network);

- e-shops (for example, Porta-shop that sells microelectronics and much more, Ozon, etc.) that use the Internet as a means of electronic 
communications, in particular for the transmission and execution of orders and electronic payments;

- network forms of product promotion - network of shops, network of promoters (multi-level organizations being built to promote products and services from the manufacturer to the consumer, using a direct human contact with a person, that is, multi-level network marketing).

The active part of electronic franchising remains a person specially trained to own a computer, including Internet technologies. This specialist becomes the director of the virtual e-shop and performs the functions of the manager in the organization of information flows.

Email. The Internet has opened fundamentally new business opportunities. Computer systems have begun to be used as a medium for communication between humans since the mid-1970s. At that time, experiments on the study of the possibilities of computer communication between people on the basis of electronic information exchange systems began. Systems for transporting messages between people using computers are called e-mail systems.

E-mail is a postal service in which messages are delivered electronically via computers.

E-mail is the basis of any business. E-mail is a powerful and convenient means of communication that essentially outperforms traditional mail by speed and facsimile connection at the cost of information transfer. E-mail facilitates business negotiations.

Significant difference in e-mail from the usual is that the "local branch of communication" is very small and serves only the user's computer, it (as a personal "mailbox" for sent messages) is always "at hand" - in the computer. More details on email will be discussed further.

E-marketing. The main function of e-marketing is the study of demand, pricing issues, advertising, sales promotion, product range planning, and more. Advertising, goods, strategy, price - all depends on the needs of customers. At the moment, individual marketing on the Internet began to develop.

The development of Internet marketing is associated with the opportunities that the Internet provides to various companies:

- carrying out of advertising actions of firm, goods, services, organizational measures;

- marketing market research; 
- analysis of competitors' activity, demand for products and advertising effectiveness;

- establishment of business relations with partners;

- search for new customers and partners.

The basis of any marketing company on the Internet is the corporate Web site of the company or company around which the entire marketing system is built. In order to attract visitors to their Web-server, the company should advertise it through registration in search engines, Web-directories, links to other Web sites, banners, thematic mailing lists.

Also, the effectiveness of marketing activities on the Internet is ensured by the advantages of e-mail (e-mail marketing):

- E-mail is practically available to all Internet users;

- Possibility of personifying messages and actions on the target audience;

- modern mail clients support the html-format of letters, which allows you to place not only text ads, but also graphic ads in the letters.

Electronic Operational Resources Management (ORM). ORM carries out advertising, sale, delivery of non-manufactured goods.

Electronic Supply Management. Electronic supply management delivers offers, goods, services, information on the Web.

Electronic brokerage services. Electronic brokerage services services in the securities market, providing a sales agreement between a potential seller and buyer.

The Internet provides new opportunities for brokerage activities. Big banks, equity houses and investment firms are actively involved in the online brokerage market, with the volume of such services becoming more and more extensive. Brokers also compete by providing customers with bank accounts and money market services online.

The volume of electronic brokerage operations is directly related to the possibility of access to the Internet, which, in turn, depends on many factors and, above all, on the level of income per capita.

\section{CRM-care for the consumer}

Over the past few years, we are experiencing a real boom in customer relationship management (CRM). This concept today has become an important tool in the hands of a businessman or owner of his own business, who cares about the future of his company. The concept 
itself is simple - instead of caring for consumers, caring for the Consumer. Moreover, about each of them, individually. The collected and processed customer information (history of purchases, tastes, needs and preferences) is used to more precisely specify the offers of a particular client, which he will accept with a high degree of probability. Naturally, in the presence of an ever-increasing number of "benevolent" clients, this approach can only be realized on the basis of the use of modern information technologies. In traditional marketing oriented consumerism, which implements the classical formula "product - positioning promotion - value / price", there is no need for interaction with a particular buyer, the differentiation of specific groups of consumers, the identification of the individual needs of customers. It could be argued that for the concept of CRM, the introduction of new technologies is not mandatory. Here are examples that show the opposite.

The implementation of the CRM-concept should involve the majority of corporate services and departments - marketing, production planning, customer support, territorial sales divisions and service services. Contacts with the client should be carried out continuously in a direct or indirect form. A special notion of "Point of Contact" ("Point of Contact") has been introduced in the CRM concept to illustrate ways of engaging with the client.

Customer Relationship Management System - the target corporate information CRM system or subsystem included in the ERP system is designed to improve customer service by maintaining customer information, customer relationship history, establishment and improvement of business procedures on the basis of stored information and subsequent assess their effectiveness.

The basic principles of building a CRM system are the following:

- having one repository of information that contains all available information about all cases of customer interaction;

- synchronization of control of interaction channels;

- collection and continuous analysis of customer information.

Thus, this approach implies that with any interaction with the client through any channel, the employee of the organization is available full information about all customer relationships and the decision is made on its basis, information about which, in turn, is also stored and is available for all future interactions. 
Table 1

Comparison of different marketing approaches

\begin{tabular}{|c|c|c|c|c|}
\hline Concept & Identification & Differentiation & Interaction & Personalization \\
\hline Goal & $\begin{array}{c}\text { Customer } \\
\text { identification }\end{array}$ & $\begin{array}{c}\text { Assessment } \\
\text { of the client } \\
\text { and his needs }\end{array}$ & $\begin{array}{c}\text { Creating } \\
\text { long-term } \\
\text { relationships }\end{array}$ & $\begin{array}{l}\text { Realization of } \\
\text { client's needs }\end{array}$ \\
\hline $\begin{array}{c}\text { Traditional } \\
\text { marketing }\end{array}$ & Unrealizable & $\begin{array}{c}\text { Cluster } \\
\text { differentiation }\end{array}$ & $\begin{array}{c}\text { Telephone } \\
\text { Call center }\end{array}$ & Sales / services \\
\hline CRM & $\begin{array}{c}\text { Profiling } \\
\text { a customer's } \\
\text { identity }\end{array}$ & $\begin{array}{c}\text { Analysis of the } \\
\text { personal level }\end{array}$ & $\begin{array}{c}\text { Automated Call } \\
\text { Center }\end{array}$ & $\begin{array}{c}\text { Sales and } \\
\text { marketing } \\
\text { automation }\end{array}$ \\
\hline $\begin{array}{c}\text { Technologic } \\
\text { al solutions }\end{array}$ & $\begin{array}{c}\text { Cookies and } \\
\text { personalization } \\
\text { of the Web client } \\
\text { profile }\end{array}$ & $\begin{array}{c}\text { Intelligence } \\
\text { and analytics }\end{array}$ & $\begin{array}{c}\text { Internet } \\
\text { applications and } \\
\text { WAP telephony }\end{array}$ & $\begin{array}{c}\text { ERP and } \\
\text { e-commerce }\end{array}$ \\
\hline
\end{tabular}

Classify the capabilities (modules) of the CRM system by functionality and levels of information processing.

Functionality can be grouped into process blocks: marketing, processing requests and wishes, sales, service.

Call-centers - inbound call processing centers (originally telephone calls, most recently all channels of communication) are usually distinguished as separate components.

Classification by information processing functions:

- operational function - registration and immediate access to primary information on the sections of the database: Events, Companies, Projects, Contacts, Documents, etc.;

- analytical function - reporting on primary data and, most importantly, in-depth analysis of information in different sections (sales funnel, analysis of results of marketing activities, analysis of sales performance in the context of products, customer segments, regions, etc.);

- cooperative function - organization of close interaction with end consumers and customers up to the influence of the client on the internal processes of the company (surveys to change the quality of the product or the order of service, Web-pages for tracking customers of the order status, SMS notification about the conducted transactions in a bank account, an opportunity for customer to independently assemble and order in real time, for example, a car or a computer with available blocks and options, etc.). 
Prior to 1993, the CRM market consisted of two main areas - Sales Force Automation (SFA) and Customer Service (CS). The primary purpose of automated territorial sales management systems was to allow sales reps to manage their customers' "points of contact" and to work with a sales plan agreed with the calendar. Over time, such systems have been enriched by the introduction of a feature management capability, which in practice has meant maintaining the tactics and methodology of sales adopted within the company, as well as being able to communicate with other units of the company, such as customer support or customer service.

Until the year 2000, CRM systems were usually "one-sided" - the socalled "contact managers", marketing support systems, or service automation systems.

The period from 2000 to 2005 is connected with the first wave of formation of joint business of companies with consumers - joint commerce (Collaborative Commerce). It is characterized by the establishment of interactive interaction of companies with their regular partners through the Internet.

Such interaction implies giving outsiders much greater access to corporate information and should therefore be based on the principles of safeguarding and trust in the partner, as well as agreed rules of operation.

2005-2007 is the time of the second wave of Collaborative Commerce, based on the even greater openness of ERP systems. Leading manufacturers have started creating interfaces for their user-friendly ERP systems, B2C e-commerce platforms have emerged, and new business infrastructure is being formed (for example, on the basis of corporate Web services in the .Net architecture). In this case, unlike the first wave, it is a matter of many-to-many interactions, that is, enterprises will cooperate not only with permanent partners, but also with all members of the business community.

Almost all modern CRM systems have more or less received the above capabilities and levels of information processing and presentation: data processing and storage in collective repositories, development of knowledge bases, Internet-based solutions for interactive interaction with the client through corporate portals, etc. An example is the Corporate Portal module of Axapta (Microsoft Business Solutions) software.

MS Axapta is a scalable system for medium to large enterprises, corporations and holding companies, providing a single integrated solution 
aimed at improving manageability and business optimization. Axapta is a powerful technology platform: its modules are open source, include integrated development environment (Morph X) and its own objectoriented programming language $(\mathrm{X}++)$, optimized for writing business applications. These tools can both modify your existing business logic and build new features.

This multifunctional ERP solution covers the business of the company as a whole, including manufacturing and distribution, supply chain management (SCM) and projects, financial management and business analysis tools, customer relationship management (CRM) and personnel management. The powerful functionality of the system greatly reduces the time and cost of creating, deploying and operating the solution.

\subsection{Concept functionality}

According to the classification of the Center for the Study of Information Technology and Organizations of the University of California, CRM systems may include the following set of functions:

- contact management - support for customer information and contact history, may include information on points of sale or periodic replenishment of customer inventory with their products;

- activity management - provides a calendar and business diary for sales representatives working in the field;

- communication management - is expressed in a standalone software module that is responsible for transmitting information using a modem or mobile phone, storing and replicating it;

- forecasting - provides information on prospective sales plans, as well as forecasts of research organizations or marketing research data of company divisions;

- Opportunity Management - Managing motivating factors for attracting leads;

- order management - obtaining information about the availability of goods in the warehouse and placing orders for the delivery or production of products online;

- documentation management - development and implementation of customizable standards and reports and promotional material;

- sales analysis - providing analytical capabilities to sales databases; 
- product configuration - storage of information about alternative products and their price characteristics;

- Encyclopedia of Marketing - Provides up-to-date information on products, prices, promotional activities, research findings (e.g., factors that influence purchasing decisions) and competitors.

Customer service acts as a factor in the after-sales relationship with the customer. Its purpose is the fast and effective solution of external and internal problems of the client.

By providing fast and accurate scenarios for solving customer problems, the company can save costs and increase the customer's sense of satisfaction and loyalty to the chosen supplier and, as a consequence, their revenue.

The following management subsystems are used to specify the directions of customer service of the CRM-system:

a) management of the customer service center: provides automated processing of the received request; collects, summarizes, analyzes customer feedback to evaluate performance, quality control and product improvement;

б) field service management: distributes, appoints and controls people with the appropriate skills and materials to serve the customer's needs; records materials, costs and time associated with customer service; provides a history of client relationships; offers valid and proven solutions by building and maintaining a knowledge base; c) management of current (Hot Line) support: solves problems by searching in the existing knowledge base; compiles, processes and maintains a problem report; informs customers about updates, new additions and models appearing in the company assortment.

Modern CRM systems integrate all the tools related to customer contact and are supported by information technologies: territorial sales management system; customer support system; marketing and sales management system; contacts and activity management.

\subsection{The main components of CRM-systems}

Software solutions aimed at improving management processes in the implementation of the CRM concept, as a rule, include the following modules: interacting CRM subsystems of individual territorial units of a distributed company; analytical and marketing software modules; electronic directories and management; an online ordering system with relevant Web services, online invoicing and the ability to pay by credit card or e-wallet. 
Since these software solutions, which are embedded in the ERP-system and continue it in the external environment, are quite complex, there are quite natural questions: "How effective is the system?", "Is the big return on a complex and expensive information system?", "What about her time, effort and money?" It can be pointed out again that the focus of the CRM concept is the consumer. The fight for the client is the essence of the market, and it will continue as long as there are market relationships. In terms of economic benefits, it is much cheaper to maintain a relationship with a regular buyer than to find a few new ones: according to the Pareto principle and based on the processing of client orders and requests, it can be shown that about $80 \%$ of the company's revenue is provided by $20 \%$ of its regular customers; sales of manufactured goods require, on average, more than ten indirect (advertising) hits to new leads to sell a unit of goods, and only 2-3 direct hits to existing loyal customers; a 5\% increase in the number of repeat customers is expressed in total by more than $25 \%$ increase in sales; making an agreement with an existing customer is easier and cheaper than reaching the same agreement with a new buyer; the average customer, frustrated at their supplier, tells about his adventures to ten acquaintances.

One of the main problems in creating and maintaining such a system of relationships is the task of maintaining the integrity and security of customer information. A company that seeks to engage with the customer more effectively while collecting the maximum amount of information about the client should take care of the non-disclosure of this information (Client Information Privacy).

The issue of collecting private information is not as simple as it might seem at first glance. There is still no consensus as to what information can be used for business purposes and which information is inadmissible, even if the client has provided it. The basic procedures that a company must implement to protect private client information include: notifying the client of the purpose of collecting information about him and its further use; the refusal of the client to establish a relationship of this nature does not mean a decrease in its value to the company in the case of long and fruitful relationship with him; an opportunity for the client to view information about him and to correct information that is not related to the internal procedures of the company (rating system, comments of contact persons, etc.); real protection against access by third parties to private information. 
Measures taken to protect private information about a customer increase the level of trust between the company and its clientele.

The CRM implementation process takes a long time on the part of the Information Technology Department. Indeed, CRM implementation is a continuous process, so IT staff must work closely with business units (planning, marketing, ordering, sales, delivery), be prepared for ongoing system support, and direct their efforts to ensure the smooth running of software applications and data structures.

Table 2

Types of CRM products

\begin{tabular}{|c|c|c|c|c|}
\hline $\begin{array}{l}\text { CRM } \\
\text { product } \\
\text { format }\end{array}$ & Cost & Disadvantages & Benefits & User profile \\
\hline 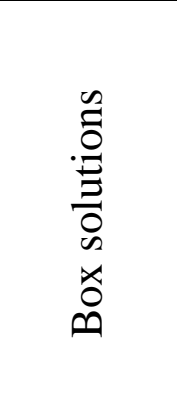 & $\begin{array}{l}\$ 200-\$ 400 \\
\text { per workplace }\end{array}$ & $\begin{array}{l}\text { Weak } \\
\text { integration } \\
\text { with other } \\
\text { applications, } \\
\text { low customi- } \\
\text { zability, } \\
\text { finishing } \\
\text { writing }\end{array}$ & $\begin{array}{l}\text { Low cost; ease of } \\
\text { implementation and } \\
\text { learning }\end{array}$ & $\begin{array}{l}\text { Small business } \\
\text { company. Number of } \\
\text { managers no more } \\
\text { than 5-10, small } \\
\text { amount of } \\
\text { information, no need } \\
\text { to connect to other } \\
\text { systems }\end{array}$ \\
\hline 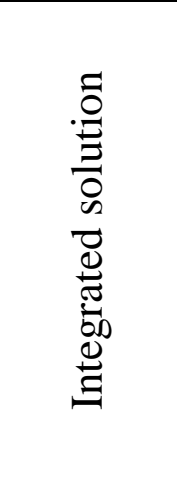 & $\begin{array}{l}\$ 600-\$ 2000 \\
\text { per workplace }\end{array}$ & $\begin{array}{l}\text { Thinly } \\
\text { represented } \\
\text { in the market }\end{array}$ & $\begin{array}{l}\text { Integration into the } \\
\text { entire IT structure of } \\
\text { the company, } \\
\text { powerful } \\
\text { functionality; } \\
\text { flexible setup for } \\
\text { business processes }\end{array}$ & $\begin{array}{l}\text { Medium Business } \\
\text { Company. Number of } \\
\text { managers 10-500, } \\
\text { large flows of } \\
\text { customer information, } \\
\text { one of the } \\
\text { requirements is the } \\
\text { integration of the IT } \\
\text { structure }\end{array}$ \\
\hline 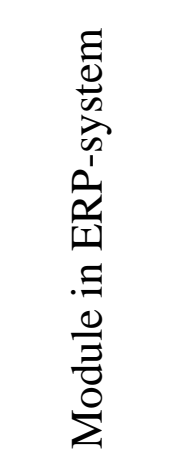 & $\begin{array}{l}\text { from } \$ 2000 \\
\text { and above }\end{array}$ & $\begin{array}{l}\text { High cost } \\
\text { and timing of } \\
\text { implementation } \\
\text { of the CRM } \\
\text { module }\end{array}$ & $\begin{array}{l}\text { No need to integrate } \\
\text { with other } \\
\text { applications; initially } \\
\text { a single information } \\
\text { environment for all } \\
\text { business units }\end{array}$ & $\begin{array}{l}\text { Large manufacturing } \\
\text { companies and } \\
\text { holdings. The number } \\
\text { of managers is } \\
\text { thousands. Requires } \\
\text { automation of all } \\
\text { processes, trans- } \\
\text { parency of the whole } \\
\text { enterprise as a whole. }\end{array}$ \\
\hline
\end{tabular}


When purchasing a ready-made solution, you should always consider which software of the class will provide the most rational "continuation" of the existing ERP-system in the client environment.

Investing in CRM is an investment in a long-term relationship with your customers and, therefore, the process of reimbursement of the investment will depend on how effective the supplier-client relationship model you create. It should be understood that CRM is not a cheap, easy and fast, but always promising solution.

\subsection{Enterprise Resource Planning, synchronized with customer requirements and expectations}

Today, the globalization of the economy, the erasure of national borders, the free movement of goods, the increasing competition, the emergence of legislative foundations in the field of product quality have led to the emergence of new requirements to meet demand and the realization of the required quality. The business is facing fundamentally new questions: "On what criteria will a buyer base his purchase decision?"; "What can be done to reduce the unproductive costs of today's competition?".

The competition formula has led manufacturers over the past decade to first and foremost focus on improving product quality and reducing its value. In the 1990s, fierce competition was concentrated around production in a short supply and just in time (JIT), and its intensification forced manufacturers to seek solutions to improve and accelerate the production process. They directed their resources to improve production efficiency, tried to produce products better, cheaper and faster.

Many changes have taken place. To adequately answer the question "Do you know the buyer?" and "Do you know exactly what the buyer wants?" requires careful consideration of the buyers - their needs and benefits. The most successful manufacturers of the last decade of the last century have found that information about a particular buyer and the realities of the market is not easy to bring together and not easy to use to increase business efficiency. The main difficulty, as it turned out, was that production efficiency could be determined, modeled, measured and achieved, and market trends were so complex and dynamic that they were difficult to measure and even more difficult to adequately predict. Production efficiency has been the result of the theory, practice and 
experience of business management over the last decade. The fastest and most predictable way to improve production performance is to increase the value of the product to the consumer (new science, new technical solutions) and reduce the value of the product by reducing costs or transforming production (using new resource-saving and information technologies) to create new product value ${ }^{3}$.

Experience has shown that production efficiency can provide shortterm benefits, but in the long run, production methods and technologies can be quickly picked up and repeated by competitors. Improved production, the widespread use of technology and more efficient business organization practices make any technological advantage a temporary factor in competitiveness. The essence of competition has changed due to the growth of business dynamics - production efficiency no longer determines long-term success in the market. But the goal remains the same - to attract new and retain a contingent of interested buyers.

The selection criterion has changed, the previously effective factors price and quality - no longer determine the choice. The buyer is not just looking for a product - he is looking for a product that meets a specific set of requirements at a particular time. New tools are needed to meet the changed requirements. As a result, a new business model has emerged Customer Synchronized Resources Planning (CSRP), which largely defines the enterprise's efforts to create a specific product needed "here and now" by a particular consumer. New relationships have emerged: a focus on the customer, not the product.

The use of ERP-systems becomes a standard approach to improving the enterprise management system. Manufacturers hoping to succeed in the growing competition in the market should actively use ERP simply to match competitors' production performance.

More and more manufacturers are introducing MRP/ERP class management systems, but as stated above, they are no longer providing pure and lasting competitive advantage. Production efficiency is always an important factor in competitiveness, but it is clearly not enough now.

The use of ERP is always focused on virtually internal processes. ERP technologies optimize enterprise management, order reception, production planning, purchase of raw materials and components, production,

\footnotetext{
${ }^{3}$ Крайников А.В., Курдиков В.А., Лебедев А.Н. и др- Вероятностные методы в вычислительной технике: Учеб. пособие для вузов по спец. ЭВМ.; Под ред. А.Н. Лебедева и Е.А. Чернявского. Москва: Высш. шк., 1986. 312 с.
} 
delivery - that is, in most cases, internal operations. But if competitive advantage is already determined by the dynamic creation and delivery of purchasing value, then the current ERP model is not enough. Manufacturers should extend the game rules to include a new player buyer - throughout the product life cycle.

Three key business questions are: "What products will the buyer require in the near future?", "Which product improvement will create competitive advantages?" and "If the fashion, tastes, and preferences of shoppers are changing at an ever-increasing rate, how can you get critical information about the market?" require increasingly effective consumer engagement technologies.

The answer is simple - integrate customer requirements and expectations with your business planning and real-time business support system.

Now the most powerful production management tools are built on the basis of the ERP kernel, but necessarily focus on integration with customers.

The system of effective production planning has two focuses - on production efficiency and on the creation of new purchasing value. This value is created through a CSRP methodology that includes a complete lifecycle - from defining the required functionality and designing a future product to meet customer requirements, to after-sales warranty and aftersales service. This new scheduling paradigm is CSRP's "synchronized resource planning".

The CSRP methodology utilizes the proven, integrated functionality of ERP systems and redirects production planning from production to customer. CSRP provides effective methods and applications for creating value-added products for the buyer. All this amounts to CSRP technology.

To implement the technology, it is necessary to: optimize production activities (operations) by building an efficient ERP-based production infrastructure; integrate buyer and customer-focused organizational units with major planning and production units; implement open technology to create a technology infrastructure that can support the integration of customers, suppliers and production management applications.

The first step in CSRP is to achieve production efficiency through the introduction of production planning technology that takes into account consumer preferences. This is especially important in areas where fashion and consumer tastes, as well as the advancement of science and the rapid 
development of technology, dictate the need for frequent changes in models and product nomenclature. Examples are the automotive industry, microelectronics, communications systems, software development, advances in nanotechnology, etc. Why not abandon the practice of using standardized ERP for other, new business practices? There are two reasons.

The first reason. ERP-based production management approaches are working - and in a number of industries, they work well. Enterprise Resource Planning is a proven methodology that utilizes a robust set of application tools that has been successfully applied in the last two decades. ERP works because it links the execution of basic operations to business logic and provides a consistent set of policies and procedures. Order processing is linked to production planning, and scheduled needs are automatically transferred to the procurement process and back. The cost of production and financial accounting are automatically changed, and critical information about operations, profitability, results of operations of units and so on become available in real time. A systematic, measurable methodology is established. Following the implementation of such a business methodology, the process of improving it can be determined, executed and repeated on a predictable basis. The second reason. An ERP-based approach is action-based. The activity of the enterprise is determined by the production process. This is a good starting point for combining customer activity. This is especially true if the manufacturer has ERP applications and processes that are focused on custom production techniques. An enterprise unable to manage customer orders has a small number of orders at a time, and they are not too different. This is critical if, with the help of CSRP, we hope to provide products that meet the customer's needs and are cost effective.

The synchronization of the requests and interests of the buyer and the departments of the customer-oriented organization with the company's executive and planning center provides the ability to identify favorable opportunities for creating differences that support competition.

The requirement to flexibly adjust production by adding real-time customer requirements to day-to-day planning and production forces business executives to pay attention not only to how critical product and market factors are to be taken into account, but to whom to do it. CSRP redefines business practices by focusing on market activity and changes in demand rather than production activity, which is planned a month or more ago. 
At the same time business processes are synchronized not only with the requirements but also with the expectations of the customers. Manufacturers that focus on customer engagement, not just production, can create benefits by developing a systematic approach to evaluation: what products to do; what services to offer; what new markets to target.

CSRP is a business methodology that moves that part of a customerfocused business to the center of a business management system. The CSRP concept establishes a methodology for doing business based on current customer information (requirements) and projected activity (expectations). CSRP shifts the enterprise focus from planning from production to planning from customer orders. Customer information and services produced are integrated into the organization's information framework.

Production planning activities are not just expanding, but are being reorganized to include customer requests transmitted from customerfocused units of the organization. For example, the order processing process is overridden. Order processing is expanding, and instead of a simple order entry feature, marketing and sales functions are integrated. The process of "ordering" now does not begin with your own order it begins with the prospects of sale:

- Sales managers do not form overall orders. They, together with buyers and in their workplace, formulate orders, identifying the needs of the buyer, which are dynamically translated into specific requirements for the products and their production at the moment. Order Configuration Technology allows you to test their suitability for completion before they are placed.

Order processing is expanding to include prospect information. Working contact management systems integrate with the order creation and production planning process to provide information about the resources needed before the order is placed. Market trends, product demand and information about competitors' offers are linked to key business processes of the company.

- Static pricing models are being replaced by a target pricing tool that allows you to determine the value of each product for each buyer, as needed. The accuracy and profitability of the products are increasing.

CSRP technology redefines customer service and extends beyond ordinary telephone support and invoicing. When using the CSRP model, the policy of selling products and services to meet general and specific 
purchasing preferences becomes the core policy of the enterprise. The Customer Support Center is responsible for bringing critical customer information to the organization's executive centers. In the general case, the interaction algorithm below is valid.

- Customer support applications integrate with key planning, production, and management applications. Critical information about buyers and goods is delivered in advance to the units responsible for production, sales, research and development, as well as to other units.

- Modern technologies for developing targeted Web services are expanding customer support, including remote, round-the-clock, selfconfiguring, a help and consultation system that operates through a corporate portal. The associated execution systems automatically integrate and account for requests, increasing the ability to provide buyers with faster answers to requests and services.

- Sales Centers also become Customer Support Centers with ongoing feedback.

Integration of planning with order processing, sales and management provides the knowledge and infrastructure to transform customer support into effective sales activities, providing a channel to promote new and related products and services.

The CSRP methodology provides effective methods and tools for creating customized products. The main mechanisms behind this technological solution are the presence of a module called Product Configurator and advanced adjustable production schedule management at limited capacity and time intervals (Advanced Planning and Scheduling - APS).

The configurator includes not only business logic and rules of order specifications formation, but also equipment composition and possible technological routes depending on different conditions. All operations are provided with several variants of time and cost of reconfiguring the equipment and its own execution, depending on the formation of a certain technological route. The data is prepared by managers of the appropriate level and is entered into the system when it is set up. It is possible to trace not only linear relations of type "if, then", but also more complex relations and logical relationships, which are calculated using the apparatus of statistical and approximating functions.

The configurator allows you to quickly and accurately estimate the cost of an order for a specific product for a particular consumer, and taking 
into account not only the individual options, but also the features of the technological process specially designed to fulfill this order. It is important that the module allows the product to be put into production immediately after completion of the configuration process, specification and price agreement with the customer.

The requesting sales manager may not be aware of all the technological relationships between production procedures, materials, and components used in the order configuration. However, it is within his competence to accept the order as soon as possible and to estimate its real cost.

The implementation of the customer's original configuration requires the ability to control production technology much more flexibly than before. In particular, the implementation of the CSRP approach requires the transition to the creation and modification of production plans immediately after the formation of each new specification. This approach cannot be implemented using the MRP/ERP systems standard (as already stated, this methodology is based on mandatory multi-stage planning - and layering plans are difficult to change because they are tied with all production and resource support processes).

To implement instantaneous modification of production plans in the CSRP methodology, the product configurator is directly linked to the Advanced Planning and Dispatcher Management (ASP) module, which uses a fundamentally new "math" to calculate and optimize production schedules and optimize equipment utilization. Unlike the MRPII-based methodology, in which the calculation of agreed production schedules is performed in off-line mode, the CSRP methodology based on the configurator and ASP module allows to calculate several variants of the on-line production schedule at the time of order acceptance with an estimate of possible costs for specific resources and re-equipment.

Thus, the planning of production and all activities is redefined and becomes the planning of customer orders for the organization of dynamic production.

The success of CSRP is to improve the quality of goods, reduce delivery times, increase the value of products for the buyer, etc. The result is a reduction in production costs, the creation of an infrastructure that is tailored to create products that meet the needs of the buyer, improve customer feedback and provide better customer service. 
A prime example is a computer sales company that offers buyers to configure their own computer system at will. After that, delivery to any specified place is made within 24 hours. Another example is the layout of a car, a yacht, an airplane from a set of components, which can be found in the catalogs of companies and on-line to form an order. The automated system calculates the necessary moment and at the right time will submit the necessary part to the assembly line.

When using the CSRP business model, traditional business processes are reviewed to serve customers and create products that meet their needs. Implementing CSRP applications pushes business leaders to change. The internal focus of traditional production structures, segmented by departments and functionality, shifts to the consumer. It is not a traditionally evaluated production efficiency that provides temporary competitive advantage; rather, it is the ability to create products that meet the customer's current needs and better service. The ability to create instantaneous purchasing value by shifting the focus from planned impersonal production to the satisfaction of a particular consumer leads to an increase in sustainable competitive advantage.

\section{REFERENCES}

1. Игер Б. Работа в Internet. Под ред. А. Тихонова; Пер. с англ. Москва: БИНОМ, 1996. 313 с.

2. Крол Эд. Все об Internet: Руководство и каталог. Пер. с англ. С.М. Тимачева. Киев: BNV, 1995. 591 с.

3. Крайников А.В., Курдиков В.А., Лебедев А.Н. и др. Вероятностные методы в вычислительной технике: Учеб. пособие для вузов по спец. ЭВМ.; Под ред. А.Н. Лебедева и Е.А. Чернявского. Москва: Высш. шк., 1986. 312 с.

\section{Information about the author:} Medvediev M. H.

Doctor of Technical Sciences, Professor,

Head at the General Engineering and Thermal Power Engineering Department of the V. I. Vernadsky Taurida National University 33, John McCain str., Kyiv, 02000, Ukraine 